\title{
A folyadékfogyasztás szerepe a sporttáplálkozásban The role of hydration in sport nutrition
}

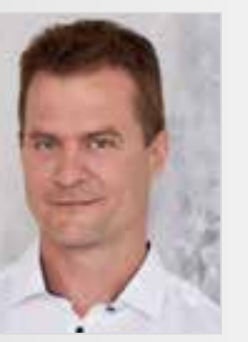

Szerzők/Authors: DR. HABIL. FRITZ PÉTER egyetemi docens/ PETER FRITZ DR. HABIL. associate professor Ferencvárosi Torna Club, Miskolci Egyetem E-mail:pfritz@hotmail.hu. Tudományos tevékenysége: doktori iskolában témavezető Scientific activity: supervisor in doctoral school Főbb kutatási terület: sporttáplálkozás, rekreáció Main areas of research: sports nutrition, recreation

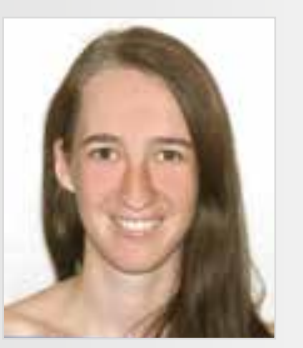

KISS ANNA/ANNA KISS Szent István Egyetem, Élelmiszertudományi Kar Szent István University, Faculty of Food Science E-mail: kiss.anna891@gmail.com

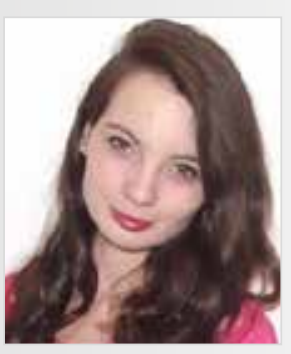

PFEIFFER LAURA/ LAURA PFEIFFER

Szent István Egyetem, Élelmiszertudományi Kar Szent István University, Faculty of Food Science E-mail:

laura.pfeiffer23@gmail.com

ÖSSZEFOGLALÁS:

Az egyénre szabott hidratációs stratégiák kulcsszerepet játszanak a sportolók sporttevékenység alatti teljesítményének optimalizálásában és egészségük megőrzésében. A sportolás a folyadék egyensúlyának akut zavarát okozhatja, kihívást jelenthet a folyadékegyensúly fenntartása a sportoló céljainak és az optimális teljesítmény megőrzése érdekében, különösen extrém környezeti feltételek esetén. Az egyéni folyadékszükségletet befolyásolja a verejtékezés mértéke, a fizikai aktivitás módja, az edzés intenzitása, a környezeti feltételek és a testmozgás időtartama.

A sportolókkal foglalkozó szakembereknek tisztában kell lenniük számos olyan élettani, logisztikai és pszichológiai tényezővel, amelyek meghatározzák a sportoló folyadékigényét a fizikai aktivitás során. Hidratációs stratégia kidolgozása és jó hidratációs gyakorlatok kialakítása szükséges a sportolók körében.

Kulcsszavak: hidratáció, biomarkerek, hidratációs állapot meghatározása, teljesítménynövelés

ABSTRACT:

Personalized hydration strategies play a key role in optimizing the performance of athletes during sporting activities and in their health promotion. Sports can cause an acute disruption to fluid balance, maintaining fluid balance to manage athlete goals and optimal performance can be a challenge, especially in extrem environmental conditions. Individual fluid intake requirements are influenced by sweat rate, physical activitate mode, workout intensity, environmental conditions and exercise duration.

Professionals, who work with athletes, should be aware of the many physiological, logistical, and psychological factors that determine an athlete's fluid requirements during physical activity. Among athletes, elaboration of a hydration strategy and developing good hydration practices are required.

Keywords: hydration, biomarkers, hydration assessment, performance enhancement

\section{A folyadékfogyasztás szerepe a sporttáplálkozásban}

Az euhidráció fenntartása, azaz a testvíz optimális homeosztatikus tartományban történő megőrzése az élet fenntartásához nélkülözhetetlen. A teljes testtömeg 50-70\%-át víz alkotja, amely az intracelluláris (65\%) és az extracelluláris (35\%) térben oszlik el. Az euhidráció a mindennapi élet során viselkedési és biológiai kontroll révén tartható fenn. A sejttérfogat-szabályozáshoz nélkülözhetetlen tápanyagot jelent a szervezet számára a víz, miközben kritikus szerepet tölt be a hő- és az általános funkciók szabályozásában. A víz menynyiségének egyensúlya, főleg a szomjúság és az antidiuretikum hormon által szabályozott (amely vazopreszin néven ismert) a vese által. A dehidratáció mértékének értékelésére a testtömeg akut csökkenése tekinthető az arany standardnak, mivel ez elsősorban a teljes testvíz csökkenését tükrözi, nem pedig az energiaszubsztrátumok (például zsír, fehérje) csökkenését. Ebben az esetben feltételezzük, hogy mind a bör (verejtékezés), mind a vese (vizelés) vízvesztésfajsúlya körülbelül 1000, ami a testtömeg 1 grammjának változását eredményezi minden verejték-milliliterjén és a vizelettel. Ez a mérési standard pontosnak tekinthető, feltételezve, hogy a bélmozgás nem számottevő, a mérést megelőző három órával nem történt élelmiszer-fogyasztás, és a testtömeget euhidratált állapotban rögzítik edzés előtt. A hipohidratált állapot a sportteljesítmény, a kognitív funkciók, a hangulat csökkenéséhez kapcsolódik, megnövekszik a hőguta és/vagy egyéb hővel kapcsolatos betegségek kockázata, különösen azon sportolóknál, akik meleg és párás környezetben edzenek (Lee et al., 2017).

A folyadékhiány kialakulásának folyamatát dehidrációnak nevezik, míg annak kimenetelét hipohidrációnak. A testvíz edzés közbeni vesztesége súlyosbítja a fiziológiai és az észlelési paramétereket, amelyek ronthatják a kitartást, a teljesítményt, különösen meleg környezetben, és növelheti a hirtelen fellépő hő miatti rosszullét kockázatát (Sawka, Wenger \& Pandolf, 2011; Trangmar \& GonzalezAlonso, 2019). Edzés közben, föleg a melegben, a legtöbb ember hajlamos kevesebbet inni, mint amennyi folyadékot izzadás által veszítenek, ennek eredménye a vízhiány (akaratlan kiszáradás). Az izzadás hipotonikus, mert testmozgás által kiváltott kiszáradás fóként az extracelluláris folyadék térfogatának csökkenését eredményezi. Ezt az állapotot hipertóniás hypovolemiaként írják le, amely a plazma vízvesztésének oka. 


\section{A hidratációs állapotot jellemző biomarkerek}

Mind a vér ozmolalitását, mind a nátriumszintet használják a hidratáció értékelésére, mivel mindkét érték arányosan növekszik a kiszáradás szintjével. Sokak számára a vér ozmolalitása jelenti a normát a hidratáció mértékének megállapítására, különös tekintettel a hidratáció akut és dinamikus változásaira. Még a csekély mértékű kiszáradás (például a testtömeg 21\%-a) is szignifikánsan növelheti a plazma ozmolalitását. A hemokoncentráció a vér biomarkere, amelyet széles körben alkalmaznak a dehidratáció mértékének megállapítására. A vér hidratációs biomarkereinek vizsgálata függ annak céljától. Az edzés előtti hidratációs állapot megmutatja, hogy a sportoló dehidratált-e edzés vagy verseny előtt. Ebben az esetben az eredmény határozza meg a folyadékfogyasztási ajánlást az edzés és a verseny során a teljesítmény megőrzése érdekében. Az edzés utáni hidratációs állapot meghatározza az egyéni folyadékfogyasztási ajánlást és az optimális regeneráció elérését is. A hidratációs állapot több nap alatti követésével meg lehet határozni, hogy a folyadék- és táplálékfelvétel kellő hidratálást biztosít-e a hidratációs állapot fenntartására a kritikus időszakok alatt is, mint az edzés, valamint a verseny előtt és után (Armstrong et al., 2013).

\section{A hidratációs állapotot jellemző vizeletmarkerek}

A plazma ozmolalitásának hemokoncentráció által vezérelt növekedése és a plazma térfogatának csökkenése az arginin vazopresszin (AVP) szekréciót stimulálja az ozmotikus receptor stimulációjával és a baroreceptorok ürítésével. Annak ellenére, hogy az AVP-t fel lehetne használni, mint a dehidratáció markerét, az analitikai eljárás költséges. Noha ez a 8 aminosav-molekula nagyon érzékeny, hajlamos gyorsan lebomlani, így a mérés kihívást jelent. Szerencsére az AVP-nek erős hatása van a vesére, növeli a víz reabszorpcióját a nephron tubulusokban. Ennek eredményeként a vizelet volumene kisebb és koncentráltabb, ezért a húgyúti koncentráció markereit is széles körben használják hidratációs indexnek. A vizeletspecifikus gravitáció és vizeletozmolalitás a hidratációs állapot változásaira érzékeny (Sawka et al., 2007; Lee et al., 2017).

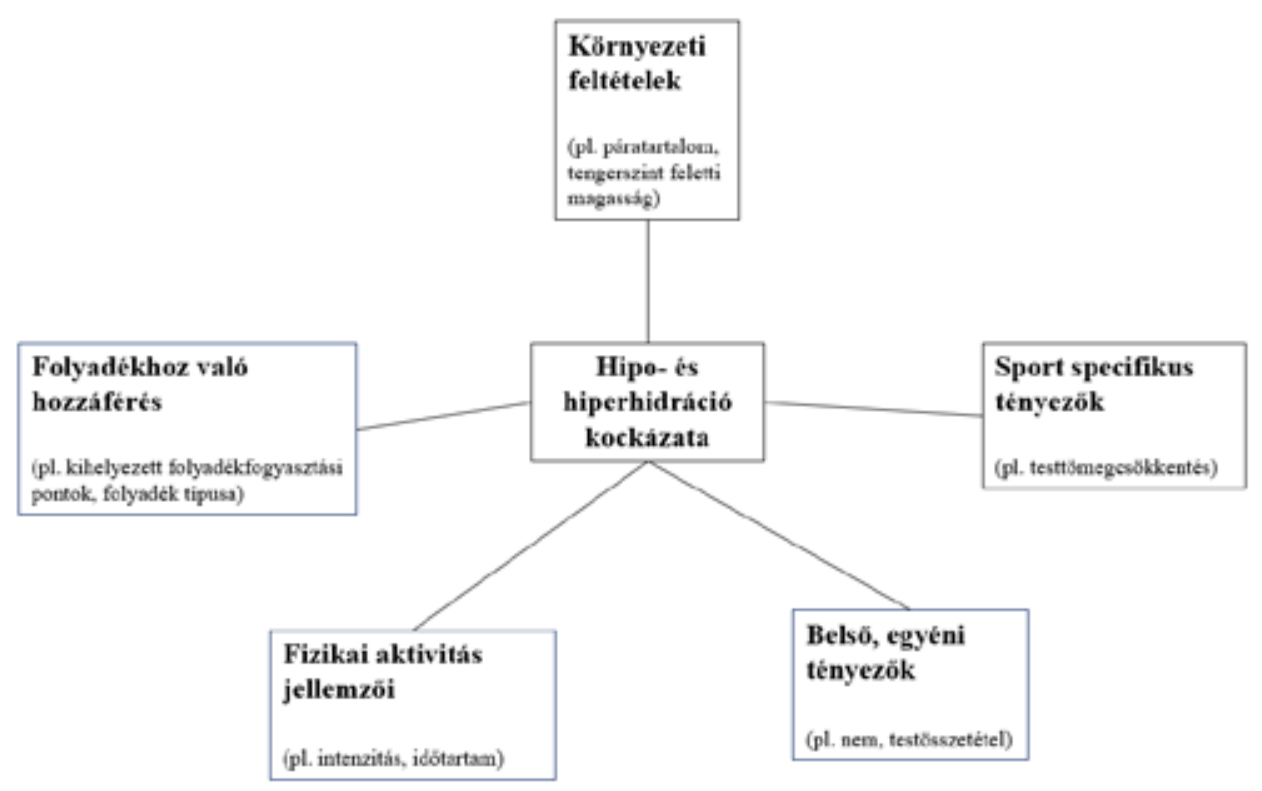

Ábra: A hipo- és hiperhidráció kialakulását befolyásoló tényezők

\section{Szomjúság}

A szomjúság észlelése is a dehidratáció markereként ismert. A szomjúságérzetet a dehidratáció stimulálja, a sportolók már akkor dehidratáltak lehetnek, mire észlelik a szomjúságot. Ez a jelenség megmagyarázhatja azt, hogy a szabadidős és profi sportolók is miért kezdik gyakran az edzésüket vagy a versenyüket egy nem optimális hidratációs állapotban, amely elmondható a megnövekedett vizelethidratációs markerek alapján. Bár a szomjúság a hidratációs állapot hasznos mérője, különösen nyugalomban, a vér vagy a vizelet biomarkerei pontosabbak lehetnek. A hidratáció egyéb jelzőiként a kutatók új biomarkereket vizsgáltak, beleértve a nyálat, az izzadságot és a könnyeket is, mint a hidratációs állapot mérésére lehetségesen alkalmazható biológiai mintákat. Bár ezen opciók nem szolgálnak a hidratációs állapot valid biomarkereként a sportolók számára, amikor a biomarkereket fontolóra veszik egy átfogó panel kiválasztására, kritikus fontosságú, hogy az újonnan tanulmányozott markereket potenciális lehetőségnek tekintsék (Lee et al., 2017).

\section{Hidratációs stratégia és jó hidratálási gyakorlatok}

A jelenlegi ajánlás szerint a jó hidratálási gyakorlat a következőket foglalja magában:

(1) edzés megkezdése euhidráció állapotban;
(2) edzés közben a túlzott hypohidráció megakadályozása;

(3) az edzés után fennmaradó veszteségek pótlása a következő edzés előtt.

Ezek a gyakorlatok enyhítik az akut kiszáradás káros hatásait a fizikai aktivitásra és az egészségre. Ugyanakkor ismert tény, hogy a folyadékigény egyéni, és olyan tényezőktől függ, mint például az egyéni verejtékezés mértéke, a fizikai aktivitás módja, az edzés intenzitása, a környezeti feltételek és a testmozgás időtartama.

Ezenkívül a sportolási környezet jellemzői és szabályai, mint az edzőruha és a felszerelés, valamint a folyadék elérhetősége az edzés és a verseny során egyaránt nagyban befolyásolhatja a test hidratációjának optimalizálására való lehetőséget (McDermott et al., 2017). A hipo- és hiperhidráció kialakulását befolyásoló tényezőket a fenti ábra mutatja.

\section{A hidratációs státusz monitorozásának módszerei}

A hidratációs státusz napi változásainak nyomon követésére alkalmazott gyakorlat a sportban több paraméter mérése és azok kombinációjának értékelése. A testtömeg napi változásainak monitorozása, a vizelet színével és a szomjúságérzettel párosítva, megfelelő érzékenységet biztosít a legtöbb sportoló helyzetében. Cheuvront és Kenefick a következő kritériumokat határozták meg: ha a testtömeg változása meghaladja az 1,1\%-ot, a szom- 
júság észlelése és a sötét színú vizelet együttesen jelzi a folyadékelégtelenséget. Ezen tényezók közül kettő teljesülése esetén a napi folyadékbevitel valószínúleg nem megfelelő, míg mindhárom tényező teljesülése azt jelzi, hogy a napi folyadékbevitel szinte biztosan nem megfelelő. Meg kell jegyezni, hogy ez az értékelési technika az első reggeli mérési értékeken alapul, és megköveteli a testtömeg alapértékeit, hogy a legkézenfekvőbb információt nyújthassák a sportolók számára (Cheuvront \& Sawka, 2005).

\section{Fizikai aktivitás}

A fizikai aktivitás intenzitása határozza meg a metabolikus hőtermelést, azaz a verejtékezésből származó folyadékveszteség aránya egy adott edzési szakasz részben magyarázható az edzés intenzitásával.

A teljes folyadékveszteség az adott edzésintenzitás verejtékezésmértéke e tevékenység teljes időtartamának az eredménye. A legtöbb esetben fordított kapcsolat van az edzés intenzitása és az edzés időtartama között. Mivel azonban az egyéni verejtékezés mértéke nagyon eltérő, az intenzitás, az időtartam és az izzadási arány közötti egyedi kölcsönhatást egyidejűleg kell figyelembe venni. Például egy futó, aki óránként két liter verejtéket ad le, és két óra alatt teljesíti a maratont, ugyanolyan folyadékveszteségeket halmoz fel, mint egy 1 l/h izzadási sebességgel bíró futó, aki négy óra alatt fejezi be a versenyt (Belval et al., 2019).

A testmozgás intenzitása befolyásolja a gyomorürülés mértékét, erôteljes testmozgást végzése esetén (> 70\% VO2max) a gyomor ürülése várhatóan csökken, valószínűleg a csökkent splanchnicus perfúzió miatt (Horner et al., 2015).

\section{A folyadékhoz való hozzáférés}

A folyadék elérhetősége olyan tényezőkre vonatkozik, amelyek meghatározzák a sportoló azon képességét, hogy pótolja a folyadékveszteséget az aktivitás során. Sok esetben a sport jellegzetességei eróteljesen befolyásolják a folyadékhoz való hozzáférést a verseny alatt. Eközben az edzések könnyen módosíthatók, hogy bizonyos fokú folyadékpótlást lehessen biztosítani.

A folyadékfogyasztást az edzés alatt a környezeti feltételek által meghatározott, az edzés és a pihenés aránya alapján lehet megbecsülni, a folyadékhoz szabad hozzáférést engedélyezve. A folyadékok tulajdonságai, mint az ízesítés és a hőmérséklet befolyásolják a folyadékok ízét, és növelhetik a folyadékbevitelt, ha megfelelnek a sportolók kulturális preferenciáinak és a körülményeknek (például hideg italok meleg környezetben) (Belval et al., 2019).

\section{Gyakorlati tippek és javaslatok a sportolók folyadék- fogyasztásának optimalizálására:}

1. Az edzés során a testtömeg akut változásainak megfigyelése szükséges a verejtékezés mértékének megbecsüléséhez, továbbá a folyadékpótlás és az edzéshez szükséges folyadékigény meghatározásához.
2. A hidratációs állapot napi változásainak nyomon követésére az ébredéskor mért testtömeg, a vizelet színe és a szomjúság mértéke együttesen használható.

3. A megnövekedett verejtéktermelés miatt megnövekedett folyadékbevitel szükséges hosszabb vagy intenzív testmozgás esetén.

4. Az edzés során célszerü arról gondoskodni, hogy a folyadékokhoz megfelelő hozzáférés legyen biztosítva, amely a sportolók számára is elfogadható.

5. A folyadékbevitel lehetőségeinek megvizsgálása szükséges, az edzésen és a versenyeken, valamint minden egyéb sporthoz kötődő eseményt meg kell vizsgálni, amely meghatározza a folyadékbevitelt.

6. Minden sporteseménynél és a sportolóknál egyéni szinten érdemes mérlegelni a hiperhidráció és a hipohidráció kialakulásának kockázatát; megfelelő hidratálási gyakorlat és oktatási stratégiák kialakítása szükséges.

7. A személyre szabott folyadékbeviteli terv készítése prioritás kell, hogy legyen, amely tartalmazza a sport vagy esemény folyadékelérhetőségi jellemzőit. Ha fennáll a hipohidráció valószínüsége, proaktív és kreatívnak kell lenni a folyadékbevitel meglévő lehetőségeinek kihasználásában a sport szabályainak keretein belül.

8. A verseny alatti folyadékfogyasztási tervet már az edzések alatt is érdemes bevezetni, hogy nyomon lehessen követni annak alkalmasságát, és elég idő legyen a folyadékfogyasztási terv átalakítására.

\section{Irodalomjegyzék}

Armstrong LE, Maughan RJ, Senay LC, Shirreffs SM. Limitations to the use of plasma osmolality as a hydration biomarker. Am J Clin Nutr 98: 503-504, 2013

Belval, L. N., Hosokawa, Y., Casa, D. J., Adams, W. M., Armstrong, L. E., Baker, L. B., ... \& Huggins, R. A. (2019). Practical Hydration Solutions for Sports. Nutrients, 11(7), 1550.

Cheuvront S.N., Sawka M.N. Hydration Assessment of Athletes. Sports Sci. Exch. 2005; 18:1-5.

Horner K.M., Schubert M.M., Desbrow B., Byrne N.M., King N.A. Acute exercise and gastric emptying: A meta-analysis and imp- lications for appetite control. Sports Med. 2015;45:659-678. doi: 10.1007/s40279-0140285-4.

Lee, E. C., Fragala, M. S., Kavouras, S. A., Queen, R. M., Pryor, J. L., \& Casa, D. J. (2017). Biomarkers in sports and exercise: tracking health, performance, and recovery in athletes. Journal of strength and conditioning research, 31(10), 2920.

McDermott B.P., Anderson S.A., Armstrong L.E., Casa D.J., Cheuvront S.N., Cooper L., Kenney W.L., O'Connor F.G., Roberts W.O. National Athletic Trainers' Association Position Statement: Fluid Replacement for the Physically Active. J. Athl. Train. 2017; 52:877895. doi: 10.4085/1062-6050-52.9.02.
Sawka M.N., Wenger C.B., Pandolf K.B. Thermoregulatory Responses to Acute Exercise-Heat Stress and Heat Acclimation. In: Terjung R., editor. Comprehensive Physiology. John Wiley \& Sons; Hoboken, NJ, USA: 2011. pp. 97-151

Sawka, M. N., Burke, L. M., Eichner, E. R., Maughan, R. J., Montain, S. J., \& StachenfeId, N. S. (2007). American College of Sports Medicine position stand. Exercise and fluid replacement. Medicine and science in sports and exercise, 39(2), 377-390.

Trangmar S.J., Gonzalez-Alonso J. Heat, Hydration and the Human Brain, Heart and Skeletal Muscles. Sports Med. 2019;49:69-85. doi: 10.1007/s40279-018-1033-y 